\title{
Temperature, taxonomic technique and the zoogeography of lugworms (Arenicolidae, Polychaeta)
}

\author{
George P. Wells \\ Department of Zoology, University College, London, England
}

\begin{abstract}
KURZFASSUNG: Temperatur, taxonomische Technik und die Zoogeographie der Wattwürmer (Arenicolidae, Polychaeta). Die Erdoberfläche läßt sich in drei große Zonen einteilen, von denen jede an ihren Küsten eine vollständig unterschiedliche Wattwurmfauna aufweist. Die Zonengrenzen entsprechen in Annäherung dem Verlauf der Sommer-200-C-Oberflächenisothermen und trennen eine nördliche und eine südliche Kaltwasserzone von einer mittleren Warmwasserzone. Die südliche Kaltwasserzone läßt einige Unterteilungen von geringer Bedeutung erkennen, und zwar entlang der $10^{\circ}$-C-Isotherme. Die Hauptzonen sind charakterisiert durch endemische Formengruppen. Offenbar haben die heutigen Temperaturschranken daher seit langer Zeit bestanden. Bis vor etwa 10 Jahren war die Klassifizierung der Arenicolidae nahezu ausschließlich auf Museumsmaterial begründet. Oft waren die Proben nur klein und nicht selten schlecht fixiert. Die Systematiker konnten daher nur sehr augenfällige Merkmale verwenden und kamen so oftmals zu Gruppen, von denen wir heute auf Grund von kombinierten Untersuchungen im Habitat und im Laboratorium wissen, daß sie zu weit gefaßt waren. In den letzten 10 Jahren ist die Zahl der Arten und Unterarten - hauptsächlich als Ergebnis einer verfeinerten Einteilung - von 10 auf 24 gestiegen. Die Bedeutung der Temperaturschranken und anderer isolierender Faktoren wird jetzt klarer erkannt. Möglicherweise werden ähnliche Studien an anderen Familien die Anzahl der Polychaetenarten, von denen bipolare oder kosmopolitische Verbreitung angenommen wird, erheblich reduzieren.
\end{abstract}

\section{INTRODUCTION}

The lugworms - of which Arenicola marina is an example - are distributed throughout the world. If we include all of the species and subspecies, twenty-four named kinds are now recognised. On the whole, the way of life and general appearance of all of them is the same. They are usually found in great numbers on beaches of muddy sand, which they swallow. They all have rather thick bodies and highly characteristic achaetous tails. On close examination, they are seen to differ from each other in many external and internal characters.

The taxonomy and zoogeography of lugworms have recently been revised in detail, in a series of six papers, each concerned with a different part of the earth's surface (Healy \& Wells 1959, Wells 1957-1963a). In this paper, I will bring to your attention some general results of that revision. 


\section{RESULTS}

The polychaete family Arenicolidae includes not only the lugworms, but also two other genera of worms which lack the specialised, achaetous tail. It is only about the true lugworms, the caudate forms, that I shall speak today. It will not be necessary to catalogue the names of all of the twenty-four kinds, but we must distinguish clearly at the start between three assemblies into which those kinds can be grouped.

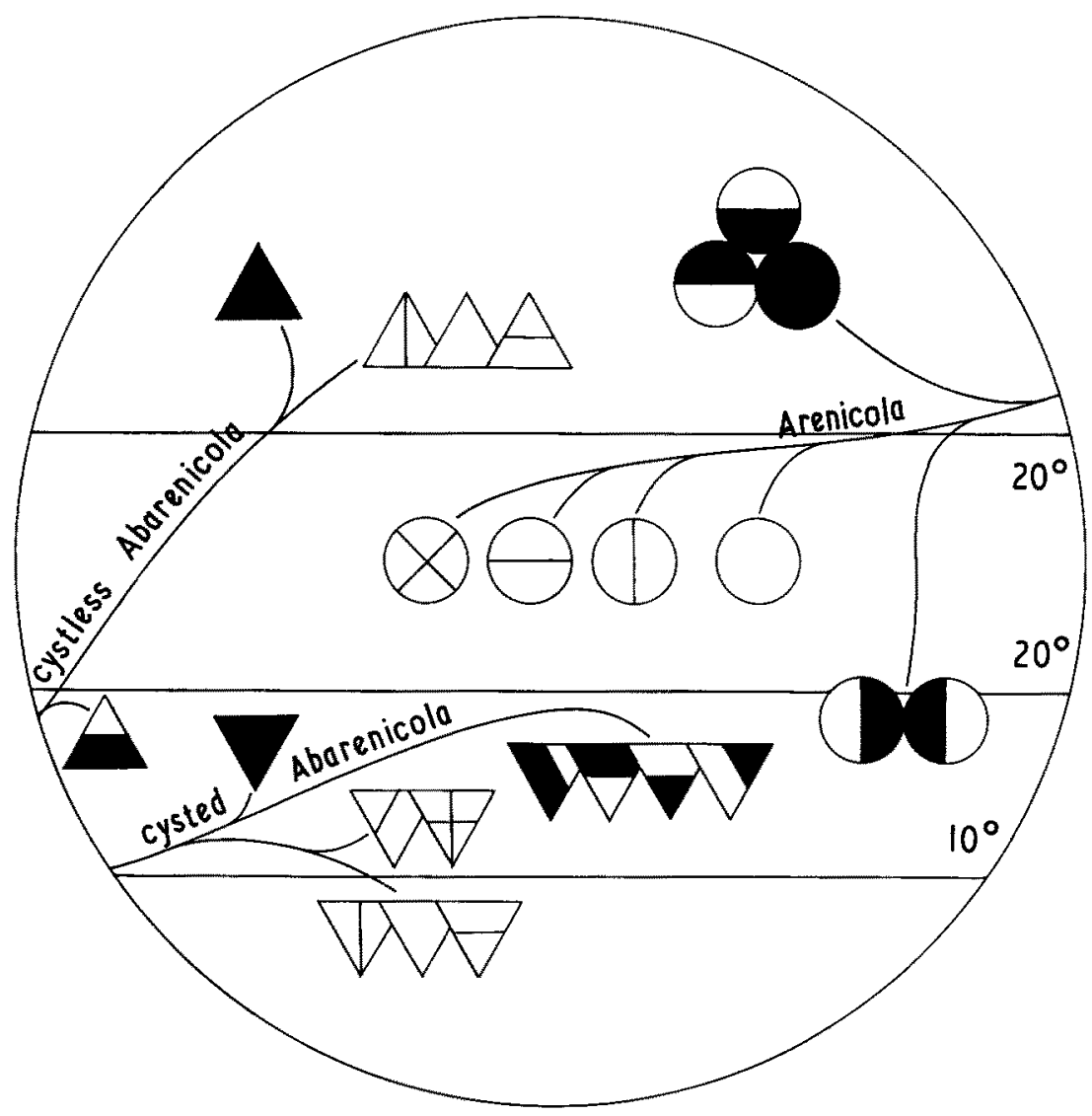

Fig. 1: The geographical distribution of lugworms

In the first place, then, the true lugworms fall into two sharply distinct genera, Arenicola and Abarenicola, differing in many important external and internal characters. In the second place, the genus Abarenicola falls into two sections, according to the presence or absence of statocysts. In most of the forms of Abarenicola - as also in Arenicola - there is a pair of statocysts near the prostomium, but in the so-called cystless section of the genus Abarenicola the statocysts have been lost, with associated modification of the lateral lobes of the prostomium.

The essentials of the story are shown in the diagram (Fig. 1). The world is divided 
into three main zones, a northern cool-water, a warm-water and a southern cool-water zone. The boundaries between them correspond roughly with the summer surfacewater isotherms for $20^{\circ} \mathrm{C}$. The southern cool-water zone shows a subdivision along the line of the $10^{\circ} \mathrm{C}$ summer isotherm.

The genus Arenicola is represented in the diagram as radiating from an ancestral stock in the northern cool-water zone. This is because Arenicola marina, a northern species, exhibits several characters that are probably primitive. At the present day, the genus consists of the following: (a) Arenicola marina with three subspecies, all in the north (black or horizontal half-black circles), (b) a group of closely interrelated species, the "cristata group" of species, which occur in warm water right around the world (white circles), and (c) Arenicola loveni with two geographically-separated subspecies, both found near the southern $20^{\circ} \mathrm{C}$ boundary line (vertical half-black circles).

The cysted Abarenicolas are presumably more primitive than the cystless ones and it seems likely that the genus, as we know it today, radiated out from ancestral forms in southern cool water. The known cysted forms include three species, respectively with one, four and five subspecies. These are all restricted to southern cool water, in which, however, they are very widely distributed. Most of them live north of the $10^{\circ} \mathrm{C}$ boundary line, but three subspecies of the species assimilis occur only below it.

We may suppose that the cystless Abarenicolas were evolved from cysted forms, probably somewhere in the south. The Southern Hemisphere still has the curious, rather aberrant Abarenicola pusilla, but most of the cystless Abarenicolas are northern cool-water forms; here we find two species, one with three subspecies.

A detailed map of the distributions of the various forms was published elsewhere (WELLS 1963b).

\section{DISCUSSION}

What conclusions may we draw from this picture?

Firstly, it is clear that temperature, acting either directly or indirectly, is a factor of outstanding importance in the control of lugworm distribution. The forms arrange themselves in a vertical spectrum, whose bands encircle the globe.

Secondly, the three main temperature zones are characterised, not merely by single species or subspecies, but by clusters of related forms. In the "cristata group" the species are very closely related to each other; they are confined to the warm-water zone, within which they seem, therefore, to have evolved and become differentiated from each other. To the north, we find that Arenicola marina has radiated into three subspecies. The cystless Abarenicolas of the northern zone share a common character which other species lack (an enlargement of the more anterior chaetigerous annuli at the expense of the ordinary annuli between them), and this marks them out as a closely interrelated cluster. The cysted Abarenicolas are restricted to the southern cool-water zone but here they have produced at least ten distinct forms.

The lugworm faunas of the three main zones have evidently been separated from 
each other for long enough to allow a considerable extent of evolutionary differentiation to take place within each zone.

Thirdly, evolutionary radiation within the main zones has been assisted by other isolating barriers, geographical and ecological. These seem, however, to be of minor importance when compared with the great temperature barriers, for they separate only subspecies, or at most single species.

The influence of geographical isolation is clearly shown by several of the species. For example, the cysted Abarenicola affinis has been found in New Zealand, in Tasmania, in South Africa and in Chile, and each of these geographically-separated populations is distinguished from the others by small, but clear and consistent, morphological characters.

The existence of ecological isolation is shown by the fact that, whenever two forms inhabit the same region, we find clear evidence of differences in habitat preference. At Friday Harbor, for example, both Abarenicola pacifica and Abarenicola claparedii vagabunda occur in the same small bay, but the first lives in gravelly and stony sand round the margins of the bay where tidal exposure is frequent and the amount of stranded plant material is high; the second, on the other hand, lives in deep, loose sand near the mouth of the bay and suffers less frequent tidal exposure. Many similar examples have been described (WeLLs 1963b).

One of them may appropriately be mentioned on this occasion, because much of the critical material was collected by the Hamburger Magalhaensische Sammelreise 1892-93 and is now in the Zoological Museum at Hamburg. The Abarenicolas of Magellan Strait and Beagle Channel, first described on the basis of this material by EHLERs, are now known to include two subspecies. Their habitats have not been compared in detail, but we have found that any one collection, made at a single place and time, consists of one only of the two subspecies. This shows that they live in separate communities, and points again to ecological isolation.

However, the conclusion which emerges most forcibly from the map is the great importance of temperature, or some factor depending on temperature. As to the problem of the mechanism by which this factor operates, I have at present no suggestion to make. There are excellent laboratories situated near the main temperature boundaries, where both warm-water and cool-water forms can be obtained together. Perhaps comparative physiological and biological studies, conducted at such stations, will guide us towards a solution of the problem.

And now, having shown you the picture, I would like to say a word about how it came to be painted, because it seems to me that the matter may have implications in a wider field than the biology of a single family of worms.

In the last ten years, the number of named species and subspecies of lugworms has risen from 10 to 24 . A small part of this rise was due to the discovery of new material, but mainly it is the result of the splitting of the older taxa. This was done for the following reasons.

Until quite recently, our classification of the Arenicolidae was based almost entirely on museum material, consisting very largely of numerically small samples, killed in various attitudes and all too often indifferently preserved. Some of the finer characters, whose significance is now becoming clear, were therefore overlooked or 
attributed to unimportant variation, and the relative significance of such easily observed characters as the number of setigers or the number of pairs of nephridia was exaggerated.

Two recent studies, made in particularly favourable localities, have shown that the resulting system was unsound. It became clear in each case, as the local naturalists had long believed, that worms which had been lumped together into one species according to the previously accepted criteria, included in fact more than one species. The first case concerned the cystless Abarenicolas of Friday Harbor, previously included in pusilla. The second concerned the warm-water Arenicolas of Woods Hole, previously lumped together as cristata. In each case, large amounts of material were available and two distinct forms occurred together in the same research area, so that they could be compared in the field and in the laboratory. It turned out that the living worms, though previously confused, could in fact be separated without difficulty, being distinct in appearance, in field behaviour, and also in such relatively indefinable characters as the kind of movements they make and their texture when held in the hand. The preserved worms, too, could readily be distinguished, but only by using characters whose importance had not previously been recognised.

It therefore became necessary to recalibrate our ideas about the kind of difference by which species should be distinguished in the Arenicolidae. The following results, which came from the recent revision, are important in the present context.

(1) Ten years ago, all of the cystless Abarenicolas were included in a single species, pusilla. Now, there are three species, one of them with three subspecies.

(2) Ten years ago, all of the cysted Abarenicolas were included in the species assimilis and its variety affinis. Now, the so-called variety has been broken up into three species, two of them with several subspecies.

(3) Ten years ago, the worms of the "cristata group" were shown as two species only, cristata and glasselli, and leading authorities had even expressed doubts as to the validity of the distinction between these two - Fauvel in print, and Ashworth in his notebooks. Now, there are believed to be four species.

These are significant changes from the zoogeographical standpoint. They should not be dismissed as minor adjustments of the taxonomist's card-indexing system. The replacement, within each temperature zone, of single species by clusters of related forms has emphasized the importance of the temperature barriers, for the existence of the clusters shows that the barriers must have persisted for a considerable time. And the only bipolar lugworm - Abarenicola pusilla - has lost its bipolar status.

One cannot help wondering whether similar taxonomic revisions, carried out on other families of Polychaeta, would not bring about comparable changes in the zoogeographical picture. The physical difficulties that, in the past, have handicapped the student of the Arenicolidae - the limitations in the amount and quality of the available material - have had their parallel elsewhere, and it is possible that some of the cases of wide geographical distributions recorded in the Polychaeta, especially bipolar and cosmopolitan distributions, are due to failure to recognise significant differences. We have come up, once again, against the central problem in taxonomic identification, of how much difference may be allowed between specimens while 
admitting them into a single taxon, and in the Arenicolidae, at least, our tolerances have, until recently, been very much too wide.

\section{SUMMARY}

1. The surface of the world may be divided into three great zones, each with a completely distinct lugworm fauna on its shores. The boundaries correspond roughly with the summer surface-water isotherms at $20^{\circ} \mathrm{C}$, and they separate a northern cool-water, a warm-water and a southern cool-water zone. The third zone shows a subdivision of minor importance along the line of the $10^{\circ} \mathrm{C}$ isotherm.

2. The main zones are characterized by endemic clusters of forms which seem to have evolved and differentiated within the zones. 'The temperature barriers must therefore have persisted for long enough to allow a considerable degree of intrazonal evolutionary differentiation to take place.

3. Until ten years ago, our classification of the Arenicolidae was based almost entirely on museum material, the samples being mostly small and sometimes illpreserved. In the circumstances, taxonomists could use only very obvious characters, and they tended to make their groups too large.

4. Recent work with large samples of worms, combining field with laboratory study, has split several of the older taxa. The number of named species and subspecies of lugworms has risen in ten years, mainly as a result of splitting, from 10 to 24 .

5. The importance of temperature barriers, and of other isolating factors, in controlling lugworm distribution is now more clearly seen. It may be that similar studies, carried out on other families, would substantially reduce the number of polychaetes supposed to have wide (bipolar or cosmopolitan) distributions.

\section{LITERATURE CITED}

Healy, E. A. \& Welis, G. P., 1959. Three new lugworms from the North Pacific area. Proc. zool. Soc. Lond. 133, 315-335.

Wells, G. P., 1957. Variation in Arenicola marina (L.) and the status of Arenicola glacialis Murdoch. Proc. Zool. Soc. Lond. 129, 397-419.

- 1959. The genera of Arenicolidae (Polychaeta). Proc. zool. Soc. Lond. 133, 301-314.

- 1961. A new lugworm from Woods Hole, hitherto included in Arenicola cristata. Proc. zool. Soc. Lond. 137, 1-11.

- 1962. The warm-water lugworms of the world. Proc. zool. Soc. Lond. 138, 331-353.

- 1963a. The lugworms of the southern cold temperate zone. Proc zool. Soc. Lond. 140, 121-159.

- 1963b. Barriers and speciation in lugworms. Speciation in the Sea. Systematics Association, London, Pub1. No. 5, 79-98.

\section{Discussion following the paper by WeLLS}

Southward: On Dr. Wells' map there seemed to be less fit between the isotherms and the distribution on the Pacific Coast. Is this a matter of actual records or of the effect of the peculiar temperature regime, or of other factors? 
WELLS: No, I don't think that is because of the records. I think that is true. There seems to be rather more overlap around Japan and around Pacific America than around the Atlantic.

LILLELUND: Is there any information on physiological differences between the different species and subspecies, for example, in the pump-effect we have seen in the work of KRÜGER.

WELLS: No. There have been no comparative studies yet. I once had a beautiful fantasy that in vacation I would go to a nice place where I would find two species side by side and make comparative physiological studies, but now with the work of Professor KrüGER and others, we know how complicated it is to make reliable physiological studies, and so I don't think it will be as easy as I had supposed. 